\title{
PENGARUH KEMASAN DAN HARGA FRESTEA TERHADAP KEPUTUSAN \\ PEMBELIAN REMAJA KOTA MEDAN
}

\author{
Andriasan Sudarso \\ Hindra Yung Cipta
}

Hasil penelitian menunjukan bahwa secara parsial, kemasan berpengaruh secara positif dan signifikan terhadap keputusan pembelian produk Frestea. Besarnya pengaruh secara parsial antara kemasan dan keputusan pembelian adalah 0,286; atau dapat dikatakan bahwa 28,6\% pengaruh kemasan terhadap keputusan pembelian konsumen dengan ketentuan variabel lainnya adalah tetap. Sedangkan harga berpengaruh secara negatif dan parsial terhadap keputusan pembelian produk Frestea. Besarnya pengaruh secara parsial antara harga dan keputusan pembelian adalah $-0,307$; atau dapat dikatakan bahwa 30,7\% pengaruh negative dari harga terhadap keputusan pembelian konsumen dengan ketentuan variabel lainnya adalah tetap. Secara serempak, kemasan dan harga berpengaruh secara signifikan terhadap keputusan pembelian konsumen. Besarnya pengaruh secara serempak antara kedua varibel tersebut dengan keputusan pembelian adalah 0,138 ; atau dapat dikatakan bahwa $13,8 \%$ pengaruh positif dari kemasan dan harga secara serempak terhadap keputusan pembelian konsumen dengan ketentuan variabel lainnya adalah tetap.

Kata Kunci ～: Kemasan, Harga, Keputusan Pembelian, Analisis Regresi Lienar Berganda. 


\section{PENDAHULUAN}

Pada pasar Indonesia, produk minuman teh memiliki tingkat penetrasi sangat tinggi, hasil survei oleh berbagai lembaga riset antara lain: AC Nielsen, MARS, dan SWA sejak tahun 1999 hingga kini menunjukkan tingkat penetrasi pasar untuk teh mencapai lebih dari 95 persen, tercatat bahwa pembagian pasar industri minuman untuk teh adalah sebesar 30 persen (SWA 10/XXI/12-25 MEI 2005). Hingga tahun 2011 terdapat sangat banyak produk minuman teh dalam kemasan yang telah beredar di Indonesia, sebut saja Teh Botol Sosro, Ultra Teh Kotak, Fruit Tea, Fres Tea, Nu Green Tea, Zes Tea, dan tren terakhir adalah dalam kemasan cup seperti Mountea, Teh Gelas, dan Tekita. Perusahaan tentunya sangat memerlukan informasi mengenai apa saja yang mempengaruhi konsumen dalam keputusan pembelian produk minuman teh dalam kemasan.

Titik tolak untuk memahami konsumen adalah perilaku konsumen yang dikembangkan sebagai usaha untuk mempermudah dalam mempelajari dan menganalisis perilaku konsumen yang sangat kompleks, terutama banyaknya variabel yang mempengaruhi dan kecenderungan untuk saling berinteraksi (Kotler dan Armstrong, 2012). Swastha dan Handoko (2000:10) menyatakan bahwa perilaku konsumen dapat didefinisikan sebagai kegiatan-kegiatan individu secara langsung terlibat dalam mendapatkan dan mempergunakan barangbarang dan jasa-jasa termasuk di dalamnya proses pengambilan keputusan pada persiapan dan penentuan kegiatan-kegiatan tersebut. Sedangkan Mowen dan Minor (2002:6) menyatakan bahwa perilaku konsumen didefinisikan sebagai studi tentang pembelian unit dan proses pertukaran yang melibatkan perolehan konsumsi dan pertukaran barang, jasa, pengalaman, serta ide.

Kemasan merupakan ujung tombak dari sebuah produk karena fungsinya yang langsung berhadapan dengan konsumen. Dengan situasi persaingan yang semakin tajam, mutlak diperlukan sebuah kemasan yang menarik. Beberapa konsumen berpendapat bahwa yang terpenting dari sebuah produk adalah produk itu sendiri, memang harus diakui bahwa kualitas barang sangatlah besar pengaruhnya terhadap tingkat penjualan dari sebuah produk, tetapi bukan berarti kemasan bisa dikesampingkan. Vernuccio, dkk (2010) mengatakan bahwa, selama dekade belakangan ini kemasan adalah alat pemasaran yang sangat serbaguna. Pernyataan tersebut sangat didukung oleh McNeal dan Ji (2003) di dalam penelitiannya menyatakan bahwa pemasaran sangat bergantung pada komunikasi visual kemasan untuk menginformasikan dan membujuk konsumen baik di titik pembelian dan pada titik konsumsi, penelitian lain yang dilakukan oleh Louchran dan Kangis (1994) menegaskan bahwa kemasan semakin diakui oleh pemasar sebagai alat penting untuk diferensiasi merek dan alat promosi di pasar.

Harga di pasar memainkan peran yang relevan dalam pengambilan keputusan konsumen, mereka mempengaruhi apa, kapan, di mana dan seberapa banyak konsumen membeli (Aalto dan Raijas, 2003). Diferensiasi juga memberikan nilai tambah bagi konsumen yang dapat dikompensasi dalam bentuk kenaikan harga. Mirip dengan itu, biaya dan manfaat pengembangan produk dan pasar baru memerlukan harga relatif tinggi, dalam membuat keputusan penentuan harga yang akurat untuk produk baru, pengetahuan yang rinci tentang potensi persepsi dan karakteristik pelanggan sangat diperlukan (Munnukka, 2008).

Banyak konsumen di Kota Medan yang melakukan keputusan pembelian produk minuman teh dalam kemasan dengan berbagai alasan. Kota Medan sebagai pusat perekonomian Provinsi Sumatera Utara, seperti pusat perdagangan, pendidikan dan perkantoran, merupakan pasar yang potensial bagi perusahaan minuman teh dalam kemasan atau distributornya dalam memasarkan produk, mengingat populasi penduduk kota Medan yang berjumlah signifikan, sehingga pada akhirnya pemasar dapat mengambil keputusankeputusan strategis.

Berdasarkan uraian diatas, maka penulis tertarik untuk mengadakan penelitian dengan judul "Pengaruh Kemasan dan Harga Frestea terhadap Keputusan Pembelian Remaja Kota Medan”.

\section{TINJAUAN PUSTAKA}

\subsection{Uraian Teoritis}

Kemasan adalah wadah atau pembungkus yang tidak hanya berfungsi 
sebagai pelindung produk selama dalam pengangkutan dan penyimpanan saja (Kotler dan Armstrong, 2012). Pengemasan adalah kegiatan-kegiatan umum dalam perencanaan barang yang melibatkan penentuan desain atau pembuatan bungkus atau kemasan bagi suatu barang. Berdasarkan pengertian diatas dapat ditarik kesimpulan bahwa pengemasan adalah kegiatan-kegiatan umum dalam perencanaan barang yang melibatkan penentuan desain atau pembuatan bungkus atau kemasan yang tidak hanya berfungsi sebagai pelindung produk selama dalam pengangkutan dan penyimpanan saja. Disamping pembungkus mengutamakan keamanan produk bagi konsumen, maka bagi para produsen pengemasan memiliki tujuan (Kotler dan Armstong, 2012) sebagai berikut:

1) Sebagai pelindung isi (protection) misalnya dari kerusakan, kehilangan, berkurangnya kadar/isi, dan sebagainya

2) Untuk memberikan kemudahan dalam pengemasan (operating) misalnya supaya tidak tumpah, sebagai alat pemegang, mudah menyemprotkannya, dan lain-lain.

3) Bermanfaat dalam pemakaian ulang (reusable) misalnya untuk diisi kembali, atau untuk wadah lain.

4) Memberikan daya tarik (promotion) yaitu aspek artistik, warna, bentuk, maupun desainnya.

5) Sebagai identitas (image) produk, misalnya berkesan kokoh, lembut, atau mewah.

6) Distribusi (shiping) misalnya mudah disusun, dihitung, dan ditangani.

7) Informasi (labelling) yaitu menyangkut isi, pemakaian dan kualitas.

8) Sebagai cerminan inofasi produk, berkaitan dengan kemajuan teknologi dan daur ulang.

Kesimpulan yang diambil dari variabel kemasan yaitu bahwa pada zaman yang modern seperti ini, banyak muncul berbagai toko-toko swalayan, konsumen semakin terdidik, maka pembungkus sangat berperan sebagai alat pemasaran. Di pasar swalayan konsumen bisa membaca sendiri segala bentuk informasi yang tertera pada pembungkus tesebut. Tujuan pengemasan oleh perusahaan yaitu agar informasi yang ada dalam pembungkus terbaca oleh konsumen, ini sudah merupakan iklan gratis bagi perusahaan. Selanjutnya kreativitas menciptakan pembungkus dengan desain mutakhir merupakan peluang berinovasi bagi para desainer.

Harga merupakan sesuatu yang diserahkan dalam pertukaran untuk mendapatkan suatu barang atau jasa (Lamb, dkk. 2001). Agar dapat sukses dalam memasarkan suatu barang atau jasa, manajer harus mengintegrasikannya dulu dengan keputusan-keputusan sebelumnya, yaitu: dalam bidang produksi, distribusi, dan strategi promosi. Penyesuaian ini dibutuhkan agar dapat menciptakan suatu bauran pemasaran yang konsisten, terpadu, dan mampu mencapai sasaran yang telah ditetapkan.

Pertimbangan-pertimbangan utama dalam penetapan harga adalah sebagai berikut (Kotler dan Armstrong, 2012):

1) Persepsi pelanggan terhadap nilai-nilai dari produk menjadi batas atas dari harga. Bila pelanggan menganggap bahwa harga lebih besar daripada nilai produk, mereka tidak akan membeli produk.

2) Biaya produksi menetapkan batas bawah bagi harga. Bila perusahaan menetapkan harga di bawah harga produksi, perusahaan akan mengalami kerugian.

3) Pertimbangan faktor internal dan eksternal perusahaan, seperti strategi dan bauran pemasaran secara keseluruhan, kondisi pasar dan permintaan, dan strategi serta harga dari pesaing.

Pengambilan keputusan merupakan suatu kegiatan individu yang secara langsung terlibat dalam mendapatkan dan mempergunakan barang atau jasa yang ditawarkan (Kotler dan Armstrong, 2012).

\subsection{Penelitian Yang Relevan}

Penelitian yang dilakukan oleh Wanti Novianti (2008), Universitas Widyatama dengan judul "Pengaruh Desain Kemasan Pouch Terhadap Keputusan Pembelian Pada Produk Teh Botol Sosro Kemasan Pouch". Penelitian dilakukan untuk mengetahui sejauh mana pengaruh desain kemasan dengan tingkat keputusan pembelian, maka dilakukan uji statistik dengan menggunakan korelasi rank spearman dan diperoleh nilai sebesar 0,874 yang menunjukan bahwa terdapat hubungan yang sangat kuat, jadi terdapat pengaruh yang sangat kuat antara desain kemasan Teh Botol Sosro kemasan pouch terhadap keputusan pembelian, sedangkan hasil analisis koefisien determinasi (Kd) sebesar 76,39 persen yang menunjukan bahwa 76,39 persen tingkat keputusan pembelian dipengaruhi oleh desain 
kemasan dan sisanya sebesar 23,61 persen dipengaruhi oleh faktor lainnya yang tidak diteliti oleh penulis. Persamaan penelitian ini dengan penelitian yang dibuat oleh peneliti adalah sama-sama menganalisis keputusan pembelian dan kemasan, sedangkan perbedaannya adalah tidak menggunakan variabel harga serta terdapat perbedaan pada teknik analisis data yang digunakan oleh peneliti.

\subsection{Kerangka Berpikir}

Berdasarkan uraian di atas yang disajikan sebagai kerangka berpikir adalah keputusan pembelian remaja kota Medan terhadap teh kemasan dalam hal ini Frestea dipengaruhi oleh kemasan dan harga Frestea tersebut. Dalam penelitian ini, dilakukan survei konsumen terhadap kemasan, harga, dan keputusan pembelian Frestea di kota Medan.

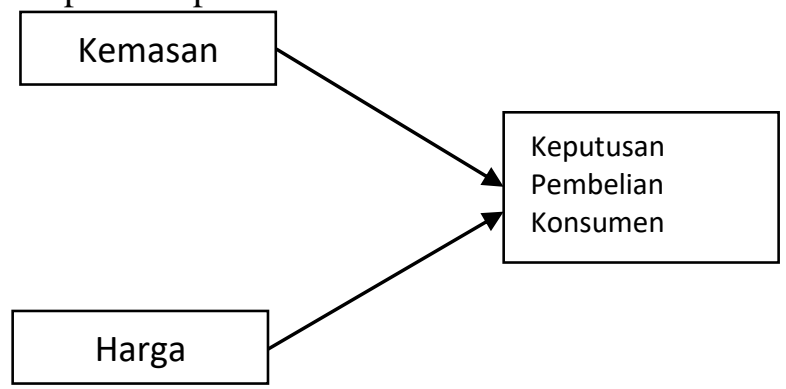

Gambar 2.1. Kerangka Berpikir

\section{METODE PENELITIAN}

Metode penelitian ini adalah penelitian deskriptif dengan menggunakan survei. Penelitian deskriptif dapat diartikan sebagai proses pemecahan masalah yang diselidiki dengan melukiskan keadaan subjek dan objek penelitian pada sekarang berdasarkan fakta-fakta yang tampak atau bagaimana adanya.

Pelaksanaan metode penelitian deskriptif tidak terbatas sampai pada pengumpulan dan penyusunan data, tetapi meliputi analisis dan interpretasi tentang data tersebut, selain itu semua yang dikumpulkan memungkinkan menjadi kunci terhadap apa yang diteliti.

\section{Hasil}

\subsection{Analisis Deskriptif}

\subsubsection{Variabel Kemasan}

Hasil dari tanggapan responden yang diperoleh adalah sebagai berikut:
Tabel 4.1. Analisis Deskriptif Pernyataan Anda

Tertarik Dengan Berbagai Macam Desain Kemasan Frestea

\begin{tabular}{|l|l|c|c|}
\hline No. & \multicolumn{1}{|c|}{ Keterangan } & Jumlah & $\begin{array}{c}\text { Persentase } \\
(\mathbf{\%})\end{array}$ \\
\hline 1 & $\begin{array}{l}\text { Sangat Tidak Setuju } \\
\text { (STS) }\end{array}$ & - & - \\
\hline 2 & Tidak Setuju (TS) & 4 & 3,6 \\
\hline 3 & Ragu-ragu (R) & 18 & 16,4 \\
\hline 4 & Setuju (S) & 47 & 42,7 \\
\hline 5 & Sangat Setuju (SS) & 41 & 37,3 \\
\hline
\end{tabular}

Sumber: Hasil Olahan Data Penelitian, 2015

Tabel 4.2. Analisis Deskriptif Pernyataan

Kemasan Frestea Sesuai Dengan Keinginan Anda

\begin{tabular}{|l|l|c|c|}
\hline No. & Keterangan & Jumlah & $\begin{array}{c}\text { Persentase } \\
(\mathbf{\%})\end{array}$ \\
\hline 1 & $\begin{array}{l}\text { Sangat Tidak Setuju } \\
\text { (STS) }\end{array}$ & 2 & 1,8 \\
\hline 2 & Tidak Setuju (TS) & 2 & 1,8 \\
\hline 3 & Ragu-ragu (R) & 17 & 15,5 \\
\hline 4 & Setuju (S) & 49 & 44,5 \\
\hline 5 & Sangat Setuju (SS) & 40 & 36,4 \\
\hline
\end{tabular}

Sumber: Hasil Olahan Data Penelitian, 2015

Tabel 4.3. Analisis Deskriptif Pernyataan Frestea Dikemas Dengan Ukuran Yang Sesuai Dengan Kebutuhan Anda

\begin{tabular}{|l|l|c|c|}
\hline No. & \multicolumn{1}{|c|}{ Keterangan } & Jumlah & $\begin{array}{c}\text { Persentase } \\
(\boldsymbol{\%})\end{array}$ \\
\hline 1 & $\begin{array}{l}\text { Sangat Tidak Setuju } \\
\text { (STS) }\end{array}$ & - & - \\
\hline 2 & Tidak Setuju (TS) & 4 & 3,6 \\
\hline 3 & Ragu-ragu (R) & 23 & 20,9 \\
\hline 4 & Setuju (S) & 37 & 33,6 \\
\hline 5 & Sangat Setuju (SS) & 46 & 41,8 \\
\hline
\end{tabular}

Sumber: Hasil Olahan Data Penelitian, 2015

Tabel 4.4. Analisis Deskriptif Pernyataan

Frestea Dikemas Dengan Bahan Yang Baik Dan Tidak Mudah Rusak

\begin{tabular}{|l|l|c|c|}
\hline No. & \multicolumn{1}{|c|}{ Keterangan } & Jumlah & $\begin{array}{c}\text { Persentase } \\
(\mathbf{\%})\end{array}$ \\
\hline 1 & $\begin{array}{l}\text { Sangat Tidak Setuju } \\
\text { (STS) }\end{array}$ & - & - \\
\hline 2 & Tidak Setuju (TS) & 4 & 3,6 \\
\hline 3 & Ragu-ragu (R) & 21 & 19,1 \\
\hline 4 & Setuju (S) & 56 & 50,9 \\
\hline 5 & Sangat Setuju (SS) & 29 & 26,4 \\
\hline
\end{tabular}

Sumber: Hasil Olahan Data Penelitian, 2015

Tabel 4.5. Analisis Deskriptif Pernyataan

Frestea Dikemas Secara Rapi

\begin{tabular}{|l|l|c|c|}
\hline No. & Keterangan & Jumlah & $\begin{array}{c}\text { Persentase } \\
(\mathbf{\%})\end{array}$ \\
\hline 1 & $\begin{array}{l}\text { Sangat Tidak Setuju } \\
\text { (STS) }\end{array}$ & - & - \\
\hline 2 & Tidak Setuju (TS) & 8 & 7,3 \\
\hline 3 & Ragu-ragu (R) & 30 & 27,3 \\
\hline 4 & Setuju (S) & 42 & 38,2 \\
\hline
\end{tabular}




\begin{tabular}{|c|c|c|c|}
\hline \\
\hline \multicolumn{4}{|c|}{$\begin{array}{c}\text { Sumber: Hasil Olahan Data Penelitian, } 2015 \\
\text { Tabel 4.6. Analisis Deskriptif Pernyataan } \\
\text { Kemasan Frestea Memudahkan Anda Untuk } \\
\text { Dibawa }\end{array}$} \\
\hline No. & Keterangan & Jumlah & $\begin{array}{c}\text { Persentase } \\
(\%)\end{array}$ \\
\hline 1 & $\begin{array}{l}\text { Sangat Tidak Setuju } \\
\text { (STS) }\end{array}$ & 3 & 2,7 \\
\hline 2 & Tidak Setuju (TS) & 12 & 10,9 \\
\hline 3 & Ragu-ragu (R) & 23 & 20,9 \\
\hline 4 & Setuju (S) & 36 & 32,7 \\
\hline 5 & Sangat Setuju (SS) & 36 & 32,7 \\
\hline
\end{tabular}

Sumber: Hasil Olahan Data Penelitian, 2015

Tabel 4.7. Analisis Deskriptif Pernyataan

Kemasan Frestea Dirancang Sehingga Anda

Mudah Mengkonsumsinya Tanpa Harus Menggunakan Alat Bantu

\begin{tabular}{|l|l|c|c|}
\hline No. & Keterangan & Jumlah & $\begin{array}{c}\text { Persentase } \\
(\mathbf{\%})\end{array}$ \\
\hline 1 & $\begin{array}{l}\text { Sangat Tidak Setuju } \\
\text { (STS) }\end{array}$ & 3 & 2,7 \\
\hline 2 & Tidak Setuju (TS) & 4 & 3,6 \\
\hline 3 & Ragu-ragu (R) & 10 & 9,1 \\
\hline 4 & Setuju (S) & 51 & 46,4 \\
\hline 5 & Sangat Setuju (SS) & 42 & 38,2 \\
\hline
\end{tabular}

Sumber: Hasil Olahan Data Penelitian, 2015

\subsubsection{Variabel Harga}

Hasil dari tanggapan responden yang diperoleh adalah sebagai berikut:

Tabel 4.8. Analisis Deskriptif Pernyataan

Harga Frestea Yang Ditawarkan Sesuai

Dengan Kualitasnya

\begin{tabular}{|l|l|c|c|}
\hline No. & Keterangan & Jumlah & $\begin{array}{c}\text { Persentase } \\
(\%)\end{array}$ \\
\hline 1 & $\begin{array}{l}\text { Sangat Tidak Setuju } \\
\text { (STS) }\end{array}$ & - & - \\
\hline 2 & Tidak Setuju (TS) & 19 & 17,3 \\
\hline 3 & Ragu-ragu (R) & 35 & 31,8 \\
\hline 4 & Setuju (S) & 41 & 37,3 \\
\hline 5 & Sangat Setuju (SS) & 15 & 13,6 \\
\hline
\end{tabular}

Sumber: Hasil Olahan Data Penelitian, 2015

Tabel 4.9. Analisis Deskriptif Pernyataan

Harga Frestea Terjangkau Oleh Daya Beli

Masyarakat Umum

\begin{tabular}{|l|l|c|c|}
\hline No. & \multicolumn{1}{|c|}{ Keterangan } & Jumlah & $\begin{array}{c}\text { Persentase } \\
(\boldsymbol{\%})\end{array}$ \\
\hline 1 & $\begin{array}{l}\text { Sangat Tidak Setuju } \\
\text { (STS) }\end{array}$ & 2 & 1,8 \\
\hline 2 & Tidak Setuju (TS) & 23 & 20,9 \\
\hline 3 & Ragu-ragu (R) & 30 & 27,3 \\
\hline 4 & Setuju (S) & 39 & 35,5 \\
\hline 5 & Sangat Setuju (SS) & 16 & 14,5 \\
\hline
\end{tabular}

Sumber: Hasil Olahan Data Penelitian, 2015
Tabel 4.10. Analisis Deskriptif Pernyataan Anda Akan Tetap Membeli Frestea, Meskipun

Harga Teh Kemasan Lain Mengalami Penurunan

\begin{tabular}{|l|l|c|c|}
\hline No. & Keterangan & Jumlah & $\begin{array}{c}\text { Persentase } \\
(\mathbf{\%})\end{array}$ \\
\hline 1 & $\begin{array}{l}\text { Sangat Tidak Setuju } \\
\text { (STS) }\end{array}$ & - & - \\
\hline 2 & Tidak Setuju (TS) & 22 & 20,0 \\
\hline 3 & Ragu-ragu (R) & 29 & 26,4 \\
\hline 4 & Setuju (S) & 43 & 39,1 \\
\hline 5 & Sangat Setuju (SS) & 16 & 14,5 \\
\hline
\end{tabular}

Sumber: Hasil Olahan Data Penelitian, 2015

Tabel 4.11 Analisis Deskriptif Pernyataan

Perkembangan Harga Frestea Cenderung Stabil

\begin{tabular}{|l|l|c|c|}
\hline No. & \multicolumn{1}{|c|}{ Keterangan } & Jumlah & $\begin{array}{c}\text { Persentase } \\
(\mathbf{\%})\end{array}$ \\
\hline 1 & $\begin{array}{l}\text { Sangat Tidak Setuju } \\
\text { (STS) }\end{array}$ & - & - \\
\hline 2 & Tidak Setuju (TS) & 18 & 16,4 \\
\hline 3 & Ragu-ragu (R) & 33 & 30,0 \\
\hline 4 & Setuju (S) & 43 & 39,1 \\
\hline 5 & Sangat Setuju (SS) & 16 & 14,5 \\
\hline
\end{tabular}

Sumber: Hasil Olahan Data Penelitian, 2015

Tabel 4.12. Analisis Deskriptif Pernyataan Apabila Harga Frestea Naik, Anda Tetap Akan Membeli Produk Tersebut

\begin{tabular}{|l|l|c|c|}
\hline No. & Keterangan & Jumlah & $\begin{array}{c}\text { Persentase } \\
(\mathbf{\%})\end{array}$ \\
\hline 1 & $\begin{array}{l}\text { Sangat Tidak Setuju } \\
\text { (STS) }\end{array}$ & 1 & 0,9 \\
\hline 2 & Tidak Setuju (TS) & 17 & 15,5 \\
\hline 3 & Ragu-ragu (R) & 33 & 30,0 \\
\hline 4 & Setuju (S) & 39 & 35,5 \\
\hline 5 & Sangat Setuju (SS) & 20 & 18,2 \\
\hline
\end{tabular}

Sumber: Hasil Olahan Data Penelitian, 2015

Tabel 4.13. Analisis Deskriptif Pernyataan Harga Frestea Sebanding/Relatif Sama Dengan Harga Teh Kemasan Yang Sejenis

\begin{tabular}{|l|l|c|c|}
\hline No. & \multicolumn{1}{|c|}{ Keterangan } & Jumlah & $\begin{array}{c}\text { Persentase } \\
(\mathbf{\%})\end{array}$ \\
\hline 1 & $\begin{array}{l}\text { Sangat Tidak Setuju } \\
\text { (STS) }\end{array}$ & 3 & 2,7 \\
\hline 2 & Tidak Setuju (TS) & 12 & 10,9 \\
\hline 3 & Ragu-ragu (R) & 23 & 20,9 \\
\hline 4 & Setuju (S) & 36 & 32,7 \\
\hline 5 & Sangat Setuju (SS) & 36 & 32,7 \\
\hline
\end{tabular}

Sumber: Hasil Olahan Data Penelitian, 2015 


\subsubsection{Variabel Keputusan Pembelian}

Hasil dari tanggapan responden yang diperoleh adalah sebagai berikut:

Tabel 4.14. Analisis Deskriptif Pernyataan

Produk Frestea Yang Ada Dapat Memenuhi Kebutuhan Anda

\begin{tabular}{|l|l|c|c|}
\hline No. & \multicolumn{1}{|c|}{ Keterangan } & Jumlah & $\begin{array}{c}\text { Persentase } \\
(\%)\end{array}$ \\
\hline 1 & $\begin{array}{l}\text { Sangat Tidak Setuju } \\
\text { (STS) }\end{array}$ & - & - \\
\hline 2 & Tidak Setuju (TS) & 3 & 2,7 \\
\hline 3 & Ragu-ragu (R) & 21 & 19,1 \\
\hline 4 & Setuju (S) & 55 & 50,0 \\
\hline 5 & Sangat Setuju (SS) & 31 & 28,2 \\
\hline
\end{tabular}

Sumber: Hasil Olahan Data Penelitian, 2015

Tabel 4.15. Analisis Deskriptif Pernyataan Anda Mengalami Kemudahan Dalam

Mendapatkan Informasi Tentang Produk Frestea

\begin{tabular}{|l|l|c|c|}
\hline No. & Keterangan & Jumlah & $\begin{array}{c}\text { Persentase } \\
(\%)\end{array}$ \\
\hline 1 & $\begin{array}{l}\text { Sangat Tidak Setuju } \\
\text { (STS) }\end{array}$ & - & - \\
\hline 2 & Tidak Setuju (TS) & 11 & 10,0 \\
\hline 3 & Ragu-ragu (R) & 27 & 24,5 \\
\hline 4 & Setuju (S) & 43 & 39,1 \\
\hline 5 & Sangat Setuju (SS) & 29 & 26,4 \\
\hline
\end{tabular}

Sumber: Hasil Olahan Data Penelitian, 2015

Tabel 4.16. Analisis Deskriptif Pernyataan

Produk Frestea Yang Ditawarkan Sesuai

Dengan Informasi Yang Anda Dapatkan

\begin{tabular}{|l|l|c|c|}
\hline No. & Keterangan & Jumlah & $\begin{array}{c}\text { Persentase } \\
(\%)\end{array}$ \\
\hline 1 & $\begin{array}{l}\text { Sangat Tidak Setuju } \\
\text { (STS) }\end{array}$ & 2 & 1,8 \\
\hline 2 & Tidak Setuju (TS) & 7 & 6,4 \\
\hline 3 & Ragu-ragu (R) & 24 & 21,8 \\
\hline 4 & Setuju (S) & 46 & 41,8 \\
\hline 5 & Sangat Setuju (SS) & 31 & 28,2 \\
\hline
\end{tabular}

Sumber: Hasil Olahan Data Penelitian, 2015

Tabel 4.17 Analisis Deskriptif Pernyataan

Manfaat Serta Harga Yang Ditawarkan Sesuai Dengan Yang Anda Inginkan

\begin{tabular}{|l|l|c|c|}
\hline No. & \multicolumn{1}{|c|}{ Keterangan } & Jumlah & $\begin{array}{c}\text { Persentase } \\
(\mathbf{\%})\end{array}$ \\
\hline 1 & $\begin{array}{l}\text { Sangat Tidak Setuju } \\
\text { (STS) }\end{array}$ & 3 & 2,7 \\
\hline 2 & Tidak Setuju (TS) & 5 & 4,5 \\
\hline 3 & Ragu-ragu (R) & 19 & 17,3 \\
\hline 4 & Setuju (S) & 54 & 49,1 \\
\hline 5 & Sangat Setuju (SS) & 29 & 26,4 \\
\hline
\end{tabular}

Sumber: Hasil Olahan Data Penelitian, 2015
One-Sample Kolmogorov-Smirnov Test

\begin{tabular}{|c|c|c|}
\hline & & $\begin{array}{l}\text { Unstandardized } \\
\text { Residual }\end{array}$ \\
\hline \multicolumn{2}{|l|}{$\mathrm{N}$} & 110 \\
\hline & Mean &, 0000000 \\
\hline \multirow[t]{3}{*}{ Normal Parameters ${ }^{\mathrm{a}, \mathrm{b}}$} & Std. & 4,09634127 \\
\hline & Deviation & \\
\hline & Absolute & ,086 \\
\hline \multirow[t]{2}{*}{ Most Extreme Differences } & Positive & ,056 \\
\hline & Negative &,- 086 \\
\hline Kolmogorov-Smirnov Z & & 899 \\
\hline Asymp. Sig. (2-tailed) & & ,394 \\
\hline
\end{tabular}

a. Test distribution is Normal.

b. Calculated from data.

Tabel 4.18. Analisis Deskriptif Pernyataan Jika ada penawaran produk yang lebih baik selain

Frestea, Anda masih tetap berniat membeli produk Frestea

\begin{tabular}{|l|l|c|c|}
\hline No. & \multicolumn{1}{|c|}{ Keterangan } & Jumlah & $\begin{array}{c}\text { Persentase } \\
(\boldsymbol{\%})\end{array}$ \\
\hline 1 & $\begin{array}{l}\text { Sangat Tidak Setuju } \\
\text { (STS) }\end{array}$ & 1 & 0,9 \\
\hline 2 & Tidak Setuju (TS) & 8 & 7,3 \\
\hline 3 & Ragu-ragu (R) & 25 & 22,7 \\
\hline 4 & Setuju (S) & 44 & 40,0 \\
\hline 5 & Sangat Setuju (SS) & 32 & 29,1 \\
\hline
\end{tabular}

Sumber: Hasil Olahan Data Penelitian, 2015

Tabel 4.19. Analisis Deskriptif Pernyataan Jika

Ada Produk Lain Yang Ditawarkan Dengan

Kualitas Yang Sama, Anda Tetap Mengkonsumsi Frestea

\begin{tabular}{|l|l|c|c|}
\hline No. & Keterangan & Jumlah & $\begin{array}{c}\text { Persentase } \\
(\mathbf{\%})\end{array}$ \\
\hline 1 & $\begin{array}{l}\text { Sangat Tidak Setuju } \\
\text { (STS) }\end{array}$ & 9 & 8,2 \\
\hline 2 & Tidak Setuju (TS) & 18 & 16,4 \\
\hline 3 & Ragu-ragu (R) & 50 & 45,5 \\
\hline 4 & Setuju (S) & 33 & 30,0 \\
\hline 5 & Sangat Setuju (SS) & 9 & 8,2 \\
\hline
\end{tabular}

Sumber: Hasil Olahan Data Penelitian, 2015

Tabel 4.20. Analisis Deskriptif Pernyataan

Anda Tidak Akan Beralih Ke Produk Lain Dan

Selalu Mengkonsumsi Frestea

\begin{tabular}{|l|l|c|c|}
\hline No. & \multicolumn{1}{|c|}{ Keterangan } & Jumlah & $\begin{array}{c}\text { Persentase } \\
(\boldsymbol{\%})\end{array}$ \\
\hline 1 & $\begin{array}{l}\text { Sangat Tidak Setuju } \\
\text { (STS) }\end{array}$ & - & - \\
\hline 2 & Tidak Setuju (TS) & 6 & 5,5 \\
\hline 3 & Ragu-ragu (R) & 28 & 25,5 \\
\hline 4 & Setuju (S) & 48 & 43,6 \\
\hline 5 & Sangat Setuju (SS) & 28 & 25,5 \\
\hline
\end{tabular}

Sumber: Hasil Olahan Data Penelitian, 2015

\subsection{Uji Asumsi Klasik}

4.2.1. Uji Normalitas

Hasil analisis data dengan uji Kolmogorov-Smirnov dapat dilihat pada tabel berikut:

Tabel 4.21. Uji Kolmogorov-Smirnov

Sumber: Olahan Data Penelitian, 2015 
Dari tabel di atas, dapat dilihat bahwa nilai Signifikansi $(0,394)$ lebih besar dari 0,05 ; sehingga dapat disimpulkan bahwa data yang diuji terdistribusi normal.

\subsubsection{Uji Multikolinearitas}

Sebagai pedoman untuk mengetahui antara variabel bebas satu dengan variabel bebas yang lain terjadi multikolinieritas jika mempunyai VIF (Varian Inflation Factor) kurang dari 10 dan angka tolerance lebih dari 0,1 .

\begin{tabular}{l} 
Tabel 4.22. Uji Varian Inflation Factor \\
\multicolumn{3}{|c|}{ Coefficients $^{\mathbf{a}}$} \\
\begin{tabular}{|ll|r|c|}
\hline \multirow{2}{*}{ Model } & \multicolumn{2}{|c|}{ Collinearity Statistics } \\
\cline { 2 - 4 } & Tolerance & VIF \\
\hline \multirow{2}{*}{$\begin{array}{l}\text { (Constant) } \\
1\end{array}$} & Kemasan &, 978 & 1,022 \\
& Harga &, 978 & 1,022 \\
\hline
\end{tabular}
\end{tabular}

a. Dependent Variable: Keputusan Pembelian Sumber: Olahan Data

Penelitian, 2015

Berdasarkan tabel 4.22 hasil uji dapat dilihat melalui Variance Inflation (VIF) masing-masing variabel independent memiliki VIF tidak lebih dari 10 dan nilai tolerance > 0,1 . Maka dapat dinyatakan model regresi linear berganda terbebas dari asumsi multikolinearitas.

\subsubsection{Uji Heterokedastisitas}

Pada penelitian ini menggunakan metode Glejser. Uji Glejser dilakukan dengan cara meregresikan antara variabel independen dengan nilai absolut residualnya. Jika nilai signifikansi antara variabel independen dengan absolut residual lebih dari 0,05 maka tidak terjadi masalah heteroskedastisitas.

Tabel 4.23 Uji Glejser Coefficients $^{\mathrm{a}}$

\begin{tabular}{|rl|r|r|}
\hline Model & & \multicolumn{1}{c|}{$\mathrm{t}$} & \multicolumn{1}{c|}{ Sig. } \\
& & & \\
\hline \multirow{2}{*}{1} & (Constant) &, 349 &, 728 \\
& Kemasan & $-2,142$ &, 028 \\
& Harga & 1,249 &, 057 \\
\hline
\end{tabular}

a. Dependent Variable: ABS_RES

Sumber: Hasil Olahan Data Penelitian, 2015
Dari output di atas dapat diketahui bahwa nilai signifikansi kedua variabel independen lebih dari 0,05. Dengan demikian dapat disimpulkan bahwa tidak terjadi masalah heteroskedastisitas pada model regresi.

\subsection{Analisis Regresi Linear Berganda}

Hasil analisis regresi linear berganda dengan menggunakan SPSS sebagai berikut:

Tabel 4.24. Analisis Regresi Linear Berganda Coefficients $^{\mathrm{a}}$

\begin{tabular}{|c|c|c|c|c|}
\hline \multicolumn{2}{|c|}{ Model } & \multicolumn{2}{|c|}{ Unstandardized Coefficients } & \multirow{2}{*}{$\begin{array}{l}\text { Standardized } \\
\text { Coefficients } \\
\text { Beta }\end{array}$} \\
\hline & & $\mathrm{B}$ & Std. Error & \\
\hline \multirow{3}{*}{1} & (Constant) & 25,950 & 3,455 & \\
\hline & Kemasan &, 253 & 092 & ,246 \\
\hline & Harga &,- 272 &, 090 &,- 271 \\
\hline
\end{tabular}

a. Dependent Variable: Keputusan Pembelian

Sumber: Olahan Data Penelitian, 2015

Dari hasil analisis regresi berganda dapat dibuat persamaan sebagai berikut:

$$
\mathrm{Y}=25,950+0,253 \mathrm{X} 1-0,272 \mathrm{X} 2
$$

1. Konstanta (a) $=25,950$, artinya apabila kemasan dan harga tetap, maka besarnya keputusan pembelian masih bernilai positif sebesar 0,246.

2. Koefisien dari variabel kemasan $(\mathrm{X} 1)=$ 0,253 , artinya apabila variabel kemasan naik satu satuan maka keputusan pembelian akan meningkat sebesar 0,253 satuan dengan asumsi variabel lainnya tetap.

3. Koefisien dari variabel Harga $(\mathrm{X} 2)=$ 0,272 , artinya apabila variabel harga naik satu satuan maka keputusan pembelian akan menurun sebesar 0,272 satuan dengan asumsi variabel lainnya tetap.

\subsection{Uji Serempak}

Hasil uji serempak dapat dilihat pada tabel 4.25. berikut:

Tabel 4.25. Uji Serempak ANOVA ${ }^{2}$

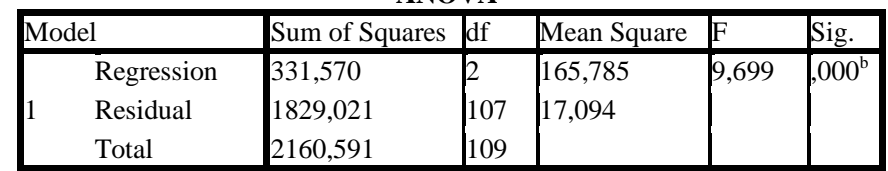

a. Dependent Variable: Keputusan Pembelian

b. Predictors: (Constant), Harga, Kemasan

Sumber: Olahan Data Penelitian, 2015

Hasil uji serempak dapat dilihat pada $\mathrm{F}$ hitung sebesar 9,699 dengan nilai sig. 0,000, karena sig. yang didapat $<\alpha=0,05$, maka hipotesis yang menyatakan ada pengaruh signifikan secara serempak antara kemasan dan harga terhadap keputusan pembelian diterima. 


\subsection{Uji Parsial}

Hasil pengujiannya dengan bantuan SPSS dapat dilihat pada tabel berikut:

Tabel 4.26. Uji Parsial Coefficients $^{\mathrm{a}}$

\begin{tabular}{|ll|r|r|}
\hline \multicolumn{1}{|l|}{ Model } & \multicolumn{1}{c|}{$\mathrm{t}$} & \multicolumn{1}{c|}{ Sig. } \\
& & & \\
\hline \multirow{2}{*}{1} & (Constant) & 7,510 &, 000 \\
& Kemasan & 2,733 &, 007 \\
& Harga & $-3,011$ &, 003 \\
\hline
\end{tabular}

a. Dependent Variable: Keputusan Pembelian

Sumber: Olahan Data Penelitian, 2015 berikut:

Hasil uji secara parsial adalah sebagai

a. Kemasan (X1), didapat t-hitung = 2,733 dengan sig. 0,007, karena sig. < $\alpha=0,05$, maka hipotesis yang menyatakan ada pengaruh yang signifikan antara kemasan terhadap keputusan pembelian diterima.

b. Harga (X2), didapat t-hitung $=-3,011$ dengan sig. 0,003, karena sig. $<\alpha=$ 0,05 , maka hipotesis yang menyatakan ada pengaruh yang signifikan antara harga terhadap keputusan pembelian diterima.

\subsection{Koefisien Determinasi}

Hasil pengolahan data dengan SPSS untuk menentukan koefisien determinasi dapat dilihat pada tabel berikut:

Tabel 4.27. Uji Koefisien Determinasi

Model Summaryb

\begin{tabular}{|l|r|r|r|r|}
\hline Model & $\mathrm{R}$ & $\begin{array}{c}\mathrm{R} \\
\text { Square }\end{array}$ & $\begin{array}{c}\text { Adjusted R } \\
\text { Square }\end{array}$ & $\begin{array}{c}\text { Std. Error of } \\
\text { the Estimate }\end{array}$ \\
\hline 1 &, $392^{\mathrm{a}}$ &, 153 &, 138 & 4,134 \\
\hline
\end{tabular}

a. Predictors: (Constant), Harga, Kemasan

b. Dependent Variable: Keputusan Pembelian

Sumber: Olahan Data Penelitian, 2015

Hasil koefesien determinasi dapat dilihat pada adjusted $\mathrm{R}$ Square $=0,138$, yang artinya besarnya kemasan dan harga dalam mempengaruhi keputusan pembelian adalah sebesar 13,8\%. Sementara sisanya sebesar $66,2 \%$ keputusan pembelian dipengaruhi oleh variabel lain yang tidak dijelaskan dalam penelitian ini. Sementara dari hasil korelasi parsial memperlihatkan kemasan mampu mempengaruhi keputusan pembelian sebesar 0,286 , sedangkan harga mampu mempengaruhi keputusan pembelian sebesar -0,307. Hasil ini memperlihatkan jika harga mempunyai pengaruh lebih besar terhadap keputusan pembelian dibandingkan dengan kemasan. Akan tetapi harga berpengaruh negatif sedangkan kemasan berpengaruh positif terhadap keputusan pembelian.

Tabel 4.28. Uji Koefisien Korelasi

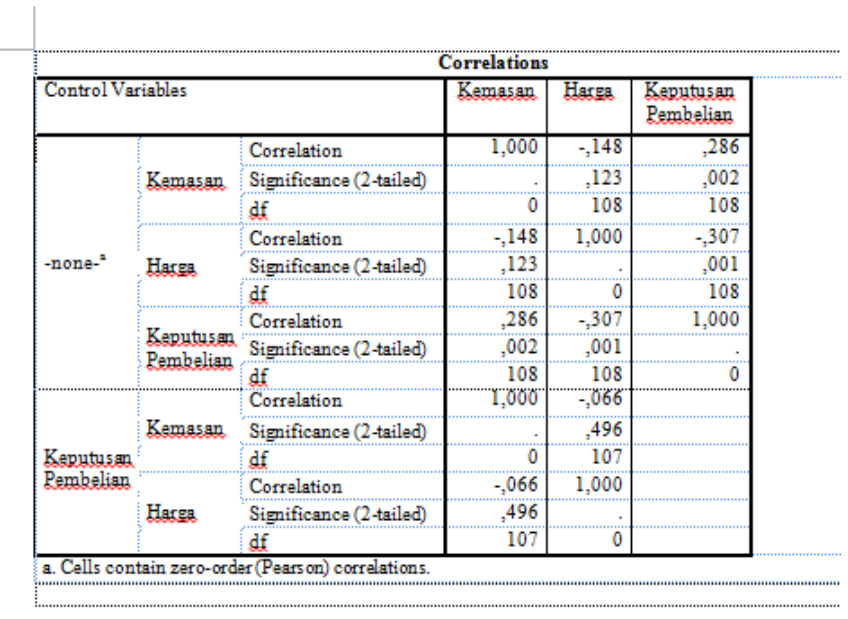

Sumber: Olahan Data Penelitian, 2015

\subsection{Pembahasan}

Hasil penelitian mengenai pengaruh kemasan dan harga Frestea terhadap keputusan pembelian remaja kota Medan memperlihatkan adanya pengaruh yang signifikan antara dari kedua variabel tersebut terhadap keputusan pembelian dari para konsumen, dimana faktor harga mempunyai pengaruh paling dominan terhadap keputusan pembelian. Hal ini memperlihatkan bahwa para konsumen memperhitungkan aspek kemasan dan harga dalam melakukan pembelian Frestea. Kesesuaian para konsumen terhadap aspekaspek yang ditawarkan akan membuat para konsumen melakukan tindakan pembelian.

\section{KESIMPULAN DAN SARAN}

\subsection{Kesimpulan}

Berdasarkan hasil penelitian yang telah dilakukan tentang pengaruh variabel kemasan dan harga Frestea terhadap keputusan pembelian remaja kota Medan, maka dapat ditarik beberapa kesimpulan sebagai berikut:

1. Secara parsial, kemasan berpengaruh secara positif dan signifikan terhadap keputusan pembelian produk Frestea. 
Besarnya pengaruh secara parsial antara kemasan dan keputusan pembelian adalah 0,286; atau dapat dikatakan bahwa $28,6 \%$ pengaruh kemasan terhadap keputusan pembelian konsumen dengan ketentuan variabel lainnya adalah tetap.

2. Secara parsial, harga berpengaruh secara negatif dan parsial terhadap keputusan pembelian produk Frestea. Besarnya pengaruh secara parsial antara harga dan keputusan pembelian adalah -0,307; atau dapat dikatakan bahwa $30,7 \%$ pengaruh negative dari harga terhadap keputusan pembelian konsumen dengan ketentuan variabel lainnya adalah tetap.

3. Secara serempak, kemasan dan harga berpengaruh secara signifikan terhadap keputusan pembelian konsumen. Besarnya pengaruh secara serempak antara kedua varibel tersebut dengan keputusan pembelian adalah 0,138 ; atau dapat dikatakan bahwa 13,8\% pengaruh positif dari kemasan dan harga secara serempak terhadap keputusan pembelian konsumen dengan ketentuan variabel lainnya adalah tetap.

\subsection{Saran}

Berdasarkan uraian hasil penelitian di atas, maka saran yang bisa diberikan adalah:

1. Sebaiknya pihak perusahaan Frestea dapat terus mengembangkan terus kemasan terutama dalam hal bentuk dan warna sehingga dapat menarik perhatian konsumen.

2. Dalam penelitian ini, harga memberikan pengaruh negative terhadap keputusan pembelian. Oleh karena itu, perusahaan sebaiknya dapat lebih bijaksana dalam menetapkan kenaikan harga, karena dengan adanya kenaikan harga akan menurunkan tingkat keputusan pembelian konsumen.

3. Dalam menetapkan harga, sebaiknya pihak perusahaan dapat mempertimbangkan harga produk teh kemasan sejenis lainnya yang dijual di pasaran, sehingga tidak akan menyebabkan adanya keraguan konsumen untuk membeli Frestea.

DAFTAR PUSTAKA

Agus Yuliyanto. 2006. Pengaruh Harga, Merek, Dan Kemasan Terhadap Keputusan Pembelian Produk Rokok Djarum Super Pada Anggota KPRI “Karya Sejahtera” Kecamatan Jekulo Kabupaten Kudus. Skripsi. Sarjana Pada Fakultas Ekonomi Universitas Negeri Semarang.

Bo Rundh. 2009. "Packaging design: creating competitive advantage with product packaging". British Food Journal Vol. 111 No. 9

Ghozali, Imam. 2006. Aplikasi : Analisis Multivariate dengan Program SPSS. Edisi 3. Semarang : Badan Penerbit Universitas Diponegoro.

Ike-Elechi Ogba and Rebecca Johnson. 2009. "How packaging affects the product preferences of children and the buyer behaviour of their parents in the food industry". Emerald Group Publishing Limited.

Kotler, Philip dan Gary Amstrong. 2012. Principles of Marketing. 14th Edition. New Jersey: Pearson Education.

Lamb, Charles W., Joseph F. Hair, dan Carl Mcdaniel. 2001. Pemasaran. Edisi Pertama. Jakarta: Salemba Empat.

Sugiyono. 2009. Metode Penelitian Bisnis. Bandung:Alfabeta.

Suyana Utama, Made. 2009. Aplikasi Analisis Kuatitatif. Denpasar : Sastra Utama.

Swastha, Basu dan Hani Handoko. 2000. Manajemen Pemasaran, Analisis Perilaku Konsumen. Edisi Pertama, Cetakan Ketiga. Yogyakarta: BPFE.

Tjiptono, Fandy. 2004. Manajemen Jasa. Yogyakarta : Andi.

Vernuccio, Maria. dkk. 2010. "An exploratory study of marketing, logistics, and ethics in packaging innovation". European Journal of Innovation Management Vol. 13 No. 3.

Ville Aalto Setala dan Anu Raijas. 2003. "Actual market prices and consumer price knowledge". Journal of Product \& Brand Management. Vol. 12 No. 3.

Wanty Novianti. 2008. Pengaruh Desain Kemasan Pouch Terhadap Keputusan Pembelian Pada Produk Teh Botol Sosro 
Kemasan Pouch. Skripsi Sarjana Jurusan Manajemen Pada Fakultas Bisnis Dan Manajemen Universitas Widyatama.

Wirawan, Nata. 2002. Statistik 2 : Statistik Inferensial. Denpasar : Keraras Emas. Yu-Jia Hu, 2008, Sevice Quality as Mediator of The relationship Between Marketing Mix Strategy and Customer Loyalty: The Case of Retailing Store in Taiwan, Journal of Marketing and Management 